\title{
The gasoline vapors spread from "small" spills in an urban environment at low wind speeds
}

\author{
Ruslan Khrestenko*1, Ekaterina Sokolova², Dmitrii Okulovsky³, Valeri Azarov ${ }^{1}$ \\ ${ }^{1}$ Volgograd State Technical University, 400074, Volgograd, Russia \\ ${ }^{2}$ North-Caucasus Federal University, 355028, Stavropol, Russia \\ 3 Tyumen Industrial University, 625000, Tyumen, Russia
}

\begin{abstract}
It is noted that the urban environment is polluted by oil products; in particular, there is a large pollution of atmospheric air. It is indicated that one of the pollution sources is the "small" spills, which are characteristic of urban areas. Experimental studies have been carried out on the gasoline distribution in atmospheric air at "small" spills. A single experiment at a low wind speed is considered. Data were obtained on the dependence of gasoline concentration in atmospheric air on the distance from the spill, the height above the level of the spill and the time of the spill. The component composition was studied using chromatographic studies. It is indicated that the distribution of gasoline vapors in the atmosphere is influenced by the ambient temperature, wind speed, surface area of the spill, time from the moment of spilling and the distance above the level of the spill. The gasoline dispersion in atmospheric air was calculated with the software using experimental and calculated data on the surface area of the spill. It is indicated that at low wind speeds (up to 0.5 $\mathrm{m} / \mathrm{s}$ ) from "small" spills of gasoline (up to 3 liters), significant excesses of standards for the content of harmful substances in the atmospheric air can be observed. It was determined that during spilling there is an excess of maximum permissible concentrations of single, hazardous substances such as ethyl benzene, m-xylene and amyl alcohol in the air.
\end{abstract}

\section{Introduction}

The urban environment is characterized by a high density of objects, both stationary and non-stationary where petroleum products are handled $[1,2,3]$, as a result environmental pollution inevitably occurs. At the same time, atmospheric air assumes a large anthropogenic load $[4,5,6]$. One of the urban air pollution sources is the numerous "small" spills of oil products. Volumes of single spills are small, but they happen all the time. Moreover, their prevalence in urban areas is extensive, such spills are observed at gas stations, parking lots, parking places, car service centers and others. So in $[7,8]$, information is given that the number of spills at fuel dispensers and at the fuel drainage site reaches up to $100 \mathrm{~g}$ per 1 ton of gasoline and $50 \mathrm{~g}$ per 1 ton of diesel fuel. In this regard, the study of the petroleum product vapors' distribution in the urban environment, caused by "small"

* Corresponding author: $40999502 @$ mail.ru 
spills of petroleum products, is an important task to obtain objective data on the environmental situation in the urban environment in relation to oil pollution.

\section{Experimental research}

To identify the dependence of petroleum products' distribution in atmospheric air at "small" spills, a series of experimental studies was carried out, since petroleum products as a rule are characterized by a multi-component composition, and the properties of each component differ significantly from each other. In general, the evaporation process of an oil product spill and the spread of its vapor in the atmosphere will be affected by meteorological conditions, the surface area of the spill, the surface properties on which the spill occurred, and oil product properties. As for the oil product properties, its volatility and / or its individual components volatility is important. The surface area affects the mass of the evaporated oil product - the larger the surface area, the greater the amount of oil product evaporating per time unit. For the urban environment during the oil products' spill, prepared coatings are characteristic - asphalt and / or concrete. Of the meteorological conditions, the most important are the temperature factor, on which the pressure of saturated vapors of oil products depends; wind speed, which affects the speed of vapor propagation and dispersion. The effect of humidity, up to $80 \%$, as shown by experiments, is not significant. The atmospheric pressure factor also affects slightly.

The essence of the research was to spill an oil product of a given volume onto the underlying surface and conduct further air sampling at points selected taking into account the direction of the wind, and determine the concentration of oil products and component composition in the samples taken. At the same time, such meteorological factors as ambient temperature, wind speed, humidity and atmospheric pressure were measured. Of particular interest is the study of petroleum vapor distribution at low wind speeds, since in this case the pollution reaches the residential area more slowly, but the dispersion is lower and the concentration is higher.

Let us consider a single experiment as an example. Gasoline was taken as an oil product, since gasoline is one of the most common types of fuel in the urban environment and has high volatility, which causes its high potential danger to air pollution. We consider AI-92-K5 gasoline brand. The gasoline volume is 3 liters, since a "small" spill of gasoline, typical of the urban environment, was modeled. During the experiment, meteorological conditions were measured at the place of the experiment. Using a meteoscope, the following parameters were determined: ambient temperature $2{ }^{\circ} \mathrm{C}$, humidity $71 \%$, atmospheric pressure $767.8 \mathrm{~mm} \mathrm{Hg}$, air velocity $0.27 \mathrm{~m} / \mathrm{s}$. The indicated volume of gasoline was spilled onto the specially prepared horizontal hard coating. The surface area of the spill determined from experimental data was $1.8 \mathrm{~m}^{2}$. To measure the distance, a measuring tape was used. The concentration was determined using a universal gas analyzer GANK-4, and the determination of the component composition using a portable gas chromatograph FGH1. Air samples at a distance from the spill were taken in the direction of wind movement and at an altitude of $0.3 \mathrm{~m}$ and $1.5 \mathrm{~m}$ above the level of the spill at different times from the moment the gasoline was spilled.

\section{Experimental results and discussion}

The results of experimental studies to determine the concentration of gasoline in the air are presented in Table 1.

Table 1. The concentration of gasoline in atmospheric air depending on the time of spilling, the height above the level of the spill, wind speed, distance from the place of spilling 


\begin{tabular}{|c|c|c|c|c|c|}
\hline № & $\begin{array}{c}\text { Time from } \\
\text { the moment } \\
\text { of the spill, } \\
\text { min }\end{array}$ & $\begin{array}{c}\text { Height } \\
\text { above the } \\
\text { level of the } \\
\text { spill, } \mathrm{m}\end{array}$ & $\begin{array}{c}\text { Wind } \\
\text { speed, } \mathrm{m} \\
/ \mathrm{s}\end{array}$ & $\begin{array}{c}\text { Distance from } \\
\text { the place of } \\
\text { the gasoline } \\
\text { spill, } \mathrm{m}\end{array}$ & $\begin{array}{c}\text { Concentration } \\
\text { of gasoline in } \\
\text { the atmospheric } \\
\text { air, mg / } \mathrm{m}^{3}\end{array}$ \\
\hline 1 & 0 & 0.3 & 0.3 & 0 & more than50 \\
\hline 2 & 3 & 1.5 & 0.3 & 0 & 7 \\
\hline 3 & 13 & 1.5 & 5.0 & 0 & 17.2 \\
\hline 4 & 17 & 1.5 & 0.3 & 0 & 0.702 \\
\hline 5 & 21 & 0.3 & 0.3 & 5 & 7.6 \\
\hline 6 & 26 & 1.5 & 0.3 & 5 & 0.269 \\
\hline 7 & 30 & 0.3 & 0.3 & 10 & 4.1 \\
\hline 8 & 35 & 1.5 & 0.3 & 10 & 0.370 \\
\hline 9 & 38 & 0.3 & 0.3 & 18 & 0.263 \\
\hline 10 & 42 & 1.5 & 0.3 & 18 & 0.245 \\
\hline 11 & 46 & 1.5 & 0.3 & 3.3 & 2.3 \\
\hline
\end{tabular}

An analysis of the data in Table 1 showed that at the initial time at a distance from the spill equal to $0 \mathrm{~m}$, the concentration of gasoline in atmospheric air above the spill level of $0.3 \mathrm{~m}$ exceeds $50 \mathrm{mg} / \mathrm{m}^{3}$, which exceeds the maximum permissible concentration of maximum one-time gasoline by more than ten times, which according to GN 2.1.6.3492-17 [9] is $5 \mathrm{mg} / \mathrm{m}^{3}$. At a height of $1.5 \mathrm{~m}$ above the spill 3 minutes after the spilling at a distance from the place of spilling equal to $0 \mathrm{~m}$, the concentration of gasoline in atmospheric air was $7 \mathrm{mg} / \mathrm{m}^{3}$, which significantly exceeds the maximum permissible concentration of single gasoline. It is important to note that at a wind speed of $5 \mathrm{~m} / \mathrm{s}, 13$ minutes after the spilling of gasoline at a height of $1.5 \mathrm{~m}$ from the level of the spill, the concentration of gasoline in the air was $17.2 \mathrm{mg} / \mathrm{m}^{3}$, which is more than 2 times the concentration of gasoline in the same place for the air sampling under the same conditions after 3 minutes from the moment of gasoline spilling. The results of chromatographic studies of air samples are presented in Table 2.

Table 2. The results of chromatographic analyzes of air samples (sample 1 - at a distance of $0 \mathrm{~m}$ from the spill at the initial time at an altitude of $0.3 \mathrm{~m}$ from the level of the spill; sample 2 - at a distance of

$3.3 \mathrm{~m}$ from the spill after 30 minutes from the moment of spilling and at a height of $1 \mathrm{~m}$ from the level of the spill)

\begin{tabular}{|c|c|c|c|c|c|}
\hline \multirow{2}{*}{$№$} & Component & \multicolumn{2}{|c|}{ Concentration, $\mathrm{mg} / \mathrm{m}^{3}$} & \multicolumn{2}{c|}{$\begin{array}{c}\text { Relative } \\
\text { concentration, \% }\end{array}$} \\
\cline { 3 - 6 } & & sample 1 & sample 2 & sample 1 & $\begin{array}{c}\text { sample } \\
2\end{array}$ \\
\hline 1 & hexane & 12.800 & 1.130 & 90.581 & 41.821 \\
\hline 2 & acetone & 0.040 & 0.032 & 0.283 & 1.185 \\
\hline 3 & ethanol & 0.126 & 0.196 & 0.892 & 7.254 \\
\hline 4 & benzene & 0.096 & 0.036 & 0.679 & 1.332 \\
\hline 5 & propyl alcohol & 0.068 & - & 0.481 & - \\
\hline 6 & toluene & 0.606 & 0.357 & 4.288 & 13.212 \\
\hline 7 & ethylbenzene & 0.074 & 0.138 & 0.524 & 5.107 \\
\hline 8 & p-xylene & 0.071 & 0.122 & 0.502 & 4.515 \\
\hline 9 & m-xylene & 0.140 & 0.274 & 0.991 & 10.141 \\
\hline 10 & o-xylene & 0.085 & 0.218 & 0.602 & 8.068 \\
\hline 11 & isoamyl alcohol & 0.025 & & 0.177 & - \\
\hline 12 & isoamyl alcohol & - & 0.056 & - & 2.073 \\
\hline
\end{tabular}




\begin{tabular}{|l|c|c|c|c|c|}
\hline 13 & amyl alcohol & - & 0.107 & - & 3.960 \\
\hline 14 & styrene & - & 0.036 & - & 1.332 \\
\hline
\end{tabular}

An analysis of the data in Table 2 showed that at the initial moment of the spilling, hexane is predominantly present in the air - at a total concentration of detected components of $14.131 \mathrm{mg} / \mathrm{m}^{3}$, the concentration of hexane is $12.800 \mathrm{mg} / \mathrm{m}^{3}$, which is approximately $90.6 \%$ of the total concentration. After 30 minutes from the moment of gasoline spill, the total concentration of the components is $2.702 \mathrm{mg} / \mathrm{m}^{3}$, that is the total concentration decreases by more than 5 times, and the concentration of hexane decreases by more than 11 times and is only $1.130 \mathrm{mg} / \mathrm{m}^{3}$, while it is about $41.8 \%$ of the total concentration. A more significant change in the concentration of hexane compared with a change in the total concentration of components is associated with its greater volatility relative to other components. The change in the concentration of other components is less significant compared with the change in the concentration of hexane. For example, the concentrations of benzene and toluene decreased by about 2.7 times and 1.7 times, respectively, the concentration of acetone changed slightly $\left(0.040 \mathrm{mg} / \mathrm{m}^{3}\right.$ and $\left.0.032 \mathrm{mg} / \mathrm{m}^{3}\right)$, and the concentration of ethyl alcohol increased by about 1.6 times, ethyl benzene about 1.9 times, p-xylene about 1.7 times, m-xylene about 2 times and o-xylene 2.6 times. The indicated differences in the concentration changes of the components are related to their volatility. In addition to the time factor, the process of changing the concentration is also affected by the factor of the distance from the spill. However, due to the low wind speed of $0.3 \mathrm{~m} / \mathrm{s}$, the distance from the spill equal to $3.3 \mathrm{~m}$, affects less significantly than the time factor.

The evaporation of gasoline spills is a complex process that is non-linear. The evaporation rate of gasoline varies significantly over time - it slows down over time, which is associated with the complex multi-component composition of gasoline. At the initial time, the main part of the evaporating oil products is represented by the volatile component - hexane, and over time, the proportion of hexane in the total mass of evaporated components decreases, since hexane has a higher evaporation rate. It should be noted that at the initial time, the concentration of toluene $0.606 \mathrm{mg} / \mathrm{m}^{3}$ is actually within the maximum single maximum concentration limit $\left(0.6 \mathrm{mg} / \mathrm{m}^{3}\right)$, and the ethyl benzene concentration $0.074 \mathrm{mg} / \mathrm{m}^{3}$ exceeds the maximum single maximum concentration $\left(0.02 \mathrm{mg} / \mathrm{m}^{3}\right)$ by more than three times. After 30 minutes from the moment of spilling, the toluene concentration in the atmospheric air is within the maximum permissible concentration of $0.357 \mathrm{mg} / \mathrm{m}^{3}$ and the ethyl benzene concentration becomes even higher $-0.138 \mathrm{mg} / \mathrm{m}^{3}$, while the maximum permissible concentration is exceeded by almost 7 times. Moreover, the concentration of m-xylene $0.274 \mathrm{mg} / \mathrm{m}^{3}$ is slightly higher than the maximum permissible concentration $\left(0.25 \mathrm{mg} / \mathrm{m}^{3}\right)$, and the concentration of such a hazardous substance as amyl alcohol is $0.107 \mathrm{mg} / \mathrm{m}^{3}$, which exceeds its maximum permissible concentration $\left.(0.010 \mathrm{mg}) / \mathrm{m}^{3}\right)$ by more than ten times.

As shown by experiments on the evaporation of gasoline, the following factors have a significant impact - ambient temperature, wind speed, spill surface area and time since the spilling. And the above factors and the distance above the level of the spill influence the distribution of gasoline vapors in the atmosphere.

\section{Theoretical research and discussion}

The gasoline dispersion based on the data of the above experiment using information from the normative and technical documentation is calculated. In the document [10] when spilling onto an unlimited surface, the area of the liquid spill $\mathrm{F}_{\text {spill }}\left(\mathrm{m}^{2}\right)$ is determined by the formula: 


$$
\mathrm{F}_{\text {spill }}=\mathrm{f}_{\text {spill }} \cdot \mathrm{V}_{\text {liq }} \text {, }
$$

where $f_{\text {spill }}$ is the spill coefficient, $\mathrm{m}^{-1}$ (equal to $150 \mathrm{~m}^{-1}$ when spilling onto a concrete or asphalt pavement);

$V_{l i q}$ - the volume of liquid entering the surrounding space, $\mathrm{m}^{3}$.

Then, using formula (1), assuming $\mathrm{f}_{\mathrm{s}}=150 \mathrm{~m}^{-1}$ and gasoline volume equal to $0.003 \mathrm{~m}^{3}$, we obtain a spill area of $0.45 \mathrm{~m}^{3}$, which differs significantly from the spill area, determined experimentally and is equal to $1.8 \mathrm{~m}^{2}$. This fact should lead to a higher evaporation rate of gasoline due to the larger surface area and, accordingly, to a higher concentration of gasoline vapor in the air.

From the information specified in the documents [10-14], to determine the evaporation rate $W, \mathrm{~kg} /\left(\mathrm{m}^{2} \mathrm{~s}\right)$ taking into account the spill of clean combustible liquid outdoors, the following formula can be used:

$$
\mathrm{W}=10^{-6} \cdot \sqrt{\mathrm{M}} \cdot\left(10^{\mathrm{A}-\frac{\mathrm{B}}{\mathrm{C}+\mathrm{t}_{\mathrm{p}}}}\right)
$$

where $M$ - the molar mass of the liquid, $\mathrm{kg} / \mathrm{kmol}$;

where $A, B, C$-constants of the Antoine equation;

$t_{p}$ - the calculated air flow temperature, ${ }^{\circ} \mathrm{C}$.

The following data on the molar masses and constants of Antoine are indicated in the document [11] for gasoline AI-93 (summer): molar mass - $98.2 \mathrm{~kg} / \mathrm{kmol}$, Antoine constants $(\mathrm{A}=4.12311, \mathrm{~B}=664.976, \mathrm{C}=221.695)$.

Taking into account the indicated data and the estimated air flow temperature equal to 2 ${ }^{\circ} \mathrm{C}$, the evaporation rate was $1.40 \times 10-4 \mathrm{~kg} /\left(\mathrm{m}^{2} \mathrm{~s}\right)$, while the maximum one-time gasoline emission taking into account the area of $0.45 \mathrm{~m}^{2}$ will be $0,63 \times 10-4 \mathrm{~kg} / \mathrm{s}$ or $0.063 \mathrm{~g} / \mathrm{s}$. In the case of using the value of the $1.8 \mathrm{~m}^{2}$ spill area obtained as a result of the experiment, the maximum one-time emission of gasoline will be $2.52 \times 10-4 \mathrm{~kg} / \mathrm{s}$ or $0.252 \mathrm{~g} / \mathrm{s}$.

Based on the obtained data, we calculated the gasoline dispersion in the atmospheric air using software package Unified Atmospheric Pollution Calculation Program UAPCP "ECOLOG" of "INTEGRAL" company (version 4.60). For the calculation, the maximum one-time gasoline emissions were taken $-0.252 \mathrm{~g} / \mathrm{s}$ and $0.063 \mathrm{~g} / \mathrm{s}$. The source of emission is accepted as areal (unorganized). The areas values of the emission source were assumed to be $1.8 \mathrm{~m}^{2}(1 \mathrm{~m} \times 1.8 \mathrm{~m})$ in accordance with the data of an experimental study and $0.45 \mathrm{~m}^{2}$ $(0.67 \mathrm{~m} \times 0.67 \mathrm{~m})$ in accordance with the calculation according to formula (1). The initial thickness of the spilled gasoline layer, determined on the basis of experimental data - the area of the spill of $1.8 \mathrm{~m}^{2}$ is $1.7 \mathrm{~mm}$, and the one determined on the basis of regulatory and technical documentation is $6.7 \mathrm{~mm}$. The dispersion of gasoline was considered in one direction at a height of $2 \mathrm{~m}$, while the value of the wind speed of $0.3 \mathrm{~m} / \mathrm{s}$ was set. As a result of the calculations, data were obtained on the concentration of gasoline in atmospheric air depending on the distance from the location of the gasoline spilling and the spill area, presented in Table 3.

Table 3. The gasoline concentration in atmospheric air at various distances from the place of the gasoline spilling with a volume of 3 liters and from the spill areas of $1.8 \mathrm{~m}^{2}$ and $0.45 \mathrm{~m}^{2}$ at a wind speed of $0.3 \mathrm{~m} / \mathrm{s}$

\begin{tabular}{|c|c|c|c|c|c|}
\hline № & $\begin{array}{c}\text { Distance } \\
\text { from the } \\
\text { point of the } \\
\text { gasoline } \\
\text { spill, } \mathrm{m}\end{array}$ & \multicolumn{2}{|c|}{$\begin{array}{c}\text { Spill area is } 1.8 \mathrm{~m}^{2} \\
\text { (initial thickness of } \\
\text { gasoline layer is } 1.7 \mathrm{~mm} \text { ) }\end{array}$} & $\begin{array}{c}\text { The spill area is } 0.45 \mathrm{~m}^{2} \\
\text { (initial gasoline layer thickness is } \\
6.7 \mathrm{~mm} \text { ) }\end{array}$ \\
\cline { 3 - 6 } & $\begin{array}{c}\text { The gasoline } \\
\text { concentration of } \\
\text { in atmospheric } \\
\text { air, } \mathrm{mg} / \mathrm{m}^{3}\end{array}$ & $\begin{array}{c}\text { MPC } \\
\text { units }\end{array}$ & $\begin{array}{c}\text { The gasoline } \\
\text { concentration } \\
\text { of in } \\
\text { atmospheric }\end{array}$ & MPC units \\
\hline
\end{tabular}




\begin{tabular}{|c|c|c|c|c|c|}
\hline & & & & air, $\mathrm{mg} / \mathrm{m}^{3}$ & \\
\hline 1 & 0 & 9.00 & 1.8 & 2.25 & 0.45 \\
\hline 2 & 5 & 8.50 & 1.7 & 2.19 & 0.438 \\
\hline 3 & 10 & 8.85 & 1.77 & 2.23 & 0.446 \\
\hline 4 & 18 & 7.55 & 1.51 & 1.9 & 0.38 \\
\hline
\end{tabular}

From the data in table 3 it can be seen that the area of the gasoline spill with the same amount of spilled gasoline significantly affects dispersion. So, in the case of the gasoline spill area determined from the experimental data $\left(1.8 \mathrm{~m}^{2}\right)$, the maximum concentration limit for maximum single gasoline is exceeded even at a distance of 18 meters from the spill place, and in the case of using the gasoline spill area $\left(0.45 \mathrm{~m}^{2}\right)$ calculated on the basis of formula (1), exceeding the maximum concentration limit maximum one-time is not observed at all.

\section{Summary}

Thus, the studies showed that at low wind speeds (up to $0.5 \mathrm{~m} / \mathrm{s}$ ) from "small" spills of gasoline (up to 3 liters), significant excesses of the standards for the content of harmful substances in atmospheric air can be observed. Moreover, according to experimental data, at an ambient temperature of $2^{\circ} \mathrm{C}$, the MPC is exceeded by the maximum single gasoline at a distance of $5 \mathrm{~m}$, and in accordance with the calculations, even at a distance of 18 meters in the direction of wind movement. It would seem that it can be assumed that the contribution of a single "small" spill of gasoline is insignificant, given the relatively small distances from the spill, at which the concentration of gasoline in atmospheric air is higher than the maximum permissible concentration. However, in the urban environment there is large number of such spills occuring constantly. In this regard, their effect on air pollution is significant. It should also be noted that the modern urban environment is characterized by the presence of a huge number of parking lots, which are located in the immediate vicinity of apartment buildings, and, as a rule, one parking lot falls on one residential building. Moreover, cars in the courtyards of apartment buildings are often located at a distance of several meters from the houses themselves, which also makes it even more important to study the influence of "small" spills on air pollution in urban areas. In this connection, the results obtained on the dispersion of gasoline from the "small" spills are of interest for the use in order to form an environmentally friendly urban environment.

Also, as a result of studies, it was found that with a "small" spill of gasoline, the maximum permissible maximum, hazardous substances such as ethyl benzene, m-xylene and amyl alcohol are exceeded in the MPC in the air.

\section{References}

1. V.R. Sayfullin, E.V. Shanina, Calculation of the damage amount from land pollution by oil products on the railways of Abakan city, International Scientific Journal "Innovation Science" v. 12, pp. 142-143 (2015).

2. T. A. Kondratyeva, R. N. Ismailova, I. B. Vybornova, Pollution level evaluation of Kazan ecosystem with heavy metals and oil products, Bulletin of Kazan Technological University, v. 16 (3), pp.171-175 (2013).

3. I.D. Feoktistova, O.N. Sakhno, A.G. Zhuravleva, Ecological condition evaluation of soils for urbanized areas contaminated with oil products, Bulletin of the Samara Scientific Center of the Russian Academy of Sciences, v. 13 (1) (5), pp.1233-1235 (2011). 
4. T.V. Noskova, E.A. Leites, O.M. Labuzova, M.S. Lysenko, The oil content in the atmosphere of Barnaul city, Socio-environmental technology, v. 2, pp. 52-60 (2018).

5. S.S. Timofeeva, S.S. Timofeev, D.V. Perminova, Unaccounted environmental load evaluation of the petroleum product supply system on the atmosphere of Irkutsk city and Irkutsk region, Bulletin of ISTU, v. 3 (50), pp. 25-29 (2011).

6. A.V. Taneeva, Environmental safety problems of roads and highways, KGASU News, v. 1 (13), pp. 376-379 (2010).

7. V.A. Yurchenko, O.G. Melnikova, Oil products' emission created by road infrastructure complexes, Bulletin of KHNADU, v. 64, pp. 134-139 (2014).

8. T.D. Yampolskaya, A.I. Fakhrutdinov, I.S. Vasilyeva, The soil and soil conditions for a number of gas stations in Surgut city, Bulletin of the Samara Scientific Center of the Russian Academy of Sciences, v. 16 (1) (4), pp. 1134-1138 (2014).

9. GN 2.1.6.3492-17 "Maximum permissible concentrations (MPC) of pollutants in the air of urban and rural settlements"

10. Methodology for determining the calculated values of fire risk at production facilities (as amended on December 14, 2010), Approved by EMERCOM order of Russia dated 10.07.2009 No. 404.

11. RD 1.2-138-2005 Methodology for assessing the fire and explosion hazard of local exhaust systems - Implementation by the order of OJSC "Gazprom" since 02/11/2005, Moscow, IRC Gazprom LLC, 2005.

12. Goremikins, D. Serdjuks, K. Buka-Vaivade, L. Pakrastins, N. Vatin. Prediction of behaviour of prestressed suspension bridge with timber deck panels. Baltic Journal of Road and Bridge Engineering. 2017. 12(4). Pp. 234-240. DOI:10.3846/bjrbe.2017.29

13. A.S. Gorshkov, P.P. Rymkevich, N.I. Vatin. Magazine of Civil Engineering. 2014. 52(8). DOI:10.5862/MCE.52.5.

14. D.A. Gura, G.G. Shevchenko, A.Y. Gura, Journal of Engineering and Applied Sciences Development research methodology elastic deformation total station 11(13), 2885-2888 (2016). DOI: 10.3923/jeasci.2016.2885.2888 